\title{
EFEKTIVITAS MODEL ICARE UNTUK MENINGKATKAN KETERAMPILAN BERPIKIR KREATIF ALAT OPTIK
}

\author{
Risda D. ${ }^{1)}$, Parsaoran S. ${ }^{1}$, R. Efendi') \\ 1)Departemen Pendidikan Fisika, Universitas Pendidikan Indonesia, JI. Dr. Setiabudhi No. 229, Bandung 40154, \\ Jawa Barat, Indonesia
}

Corresponding author: Risda D.

E-mail: risdadestari@student.upi.edu

\section{Diterima 15 April 2021, Direvisi 05 Mei 2021, Disetujui 06 Mei 2021}

\begin{abstract}
ABSTRAK
Tujuan pendidikan pada saat ini adalah untuk mendidik individu yang dapat memecahkan suatu permasalahan yang mereka temui dalam kehidupan sehari-hari. Salah satu keterampilan yang dibutuhkan untuk memecahkan permasalahan yaitu keterampilan berpikir kreatif. Keterampilan berpikir kreatif merupakan salah satu cara berpikir yang dibutuhkan dalam kehidupan kerja dan masyarakat di abad 21, yang harus dilatihkan kepad apeserta didik Ketika proses pembelajaran. Namun kenyataannya, keterampilan berpikir kreatif ini jarang sekali dilatihkan kepada peserta didik dalam proses pembelajaran. Maka penelitian ini bertujuan untuk menerapkan model pembelajaran ICARE untuk meningkatkan keterampilan berpikir kreatif peserta didik pada materi alat optik. Digunakan metode penelitian semu (quasi experiment) dengan desain one group pretest posttest. Instrumen penelitian berupa soal uraian sebanyak 12 soal yang sudah diuji validitas dan reliabilitasnya. Partisipan dalam penelitian ini adalah 24 peserta didik, dengan mengunakan teknik analisis data gain ternormalisasi untuk melihat peningkatan keterampilan berpikir kreatif dan uji effect size untuk mengetahui efek dari model pembelajaran ICARE. Hasil penelitian berupa nilai gain ternormalisasi sebesar 0,44 yang termasuk kategori sedang dengan taraf signifikansi 0,05. Selanjutnya diperoleh hasil uji effect size untuk keterampilan berpikir kreatif sebesar 3,47 yang termasuk pada kategori tinggi. Hasil ini menunjukan bahwa model pembelajaran ICARE efektif dalam meningkatkan keterampilan berpikir kreatif peserta didik pada materi alat optik.
\end{abstract}

Kata kunci: model pembelajaran ICARE; keterampilan berpikir kreatif; alat optik

\begin{abstract}
The purpose of education is to guide students to solve problems in real life. One of the skills needed to solve problems is creative thinking skills. Creative thinking skills are one of the ways of thinking that a person needs in work life and society in the 21st century. However, in reality, these creative thinking skills are not trained to students in the learning process. So, this study aims to apply the ICARE learning model to improve the creative thinking skills of class XI SMA students on optical instrument material. A quasi-experimental research method was used with a one-group pretest-posttest research design. The instrument in this study was 12 questions that were reliable and valid in terms of descriptions of creative thinking skills and were given a score of 1-4 in accordance with the assessment rubric. Participants in this study were 24 students, with data analysis techniques using N-Gain and the effect size to determine the effect of the ICARE learning model. The result of this research is a normalized gain value of 0.44 which is included in the medium category with a significance level of 0.05 . Furthermore, the effect size test results obtained for creative thinking skills of 3.47 which are included in the high category. These results that the ICARE learning model is effective in improving students' creative thinking skills in optical instrument material.
\end{abstract}

Keywords: ICARE learning model; creative thinking skills; optical material

\section{PENDAHULUAN}

Keterampilan abad-21 menjadi semakin penting untuk menjamin peserta didik memiliki keterampilan belajar dan berinovasi, keterampilan menggunakan teknologi dan media informasi, serta dapat bekerja dan bertahan dengan menggunakan keterampilan untuk hidup (life skills) (Arifin, 2017) Keterampilan yang harus dimiliki oleh setiap individu dalam rangka menghadapi tantangan di abad 21 salah satunya adalah keterampilan berpikir kreatif (Binkeley Erstad, O., Herman, J., Raizen, S., Ripley, M. \& Rumble, M., 2010; 
Trilling \& Fadel, 2009). Melatihkan keterampilan berpikir kreatif kepada peserta didik telah menjadi prioritas di abad ke-21 (Alzoubi et al., 2016; Kivunja, 2015).

Salah satu tujuan pendidikan adalah untuk mendidik individu yang dapat memecahkan permasalahan yang mereka temui dalam kehidupan sehari-hari. Salah satu keterampilan yang dibutuhkan agar dapat memecahkan permasalahan yaitu keterampilan berpikir kreatif. Keterampilan berpikir kreatif merupakan salah satu cara berpikir (ways of thinking) yang dibutuhkan seseorang dalam kehidupan kerja dan masyarakat di abad 21 (Binkeley Erstad, O., Herman, J., Raizen, S., Ripley, M. \& Rumble, M., 2010). Menurut (Torrance, 1990) keterampilan berpikir kreatif yang dimaksudkan adalah kemampuan berpikir dengan menggunakan berbagai operasi mental, yaitu kelancaran, kelenturan, keaslian, dan pengungkapan ide untuk menghasilkan sesuatu yang asli, baru dan bernilai. Keterampilan berpikir kreatif merupakan bagian dari keterampilan berpikir tingkat tinggi yang secara spesifik difokuskan pada pencarian banyak ide, pemunculan berbagai kemampuan dan banyak jawaban benar terhadap suatu permasalahan (Wibowo \& Suhandi, 2013). Oleh karena itu, guru memiliki peran penting untuk melatihkan keterampilan berpikir kreatif kepada peserta didik.

Kenyataannya berdasarkan studi pendahuluan yang telah dilakukan melalui kegiatan wawancara dengan guru fisika dan peserta didik di salah satu SMA di Bandung, menyatakan bahwa pembelajaran fisika cenderung berpusat pada guru (teacher center) dengan proses pembelajaran bersifat transfer pengetahuan sehingga kurang memberi kesempatan kepada peserta didik untuk mengungkapkan ide gagasannya, guru jarang mengajak peserta didik untuk memecahkan permasalahan dunia nyata secara kreatif sebagai upaya untuk melatihkan keterampilan berpikir kreatif dalam pemecahan masalah, soal yang diberikan kepada peserta didik cenderung pada soal-soal yang penyelesaiannya langsung pada pemakaian rumus yang sudah ada. Hal tersebut mengakibatkan, dalam proses pembelajaran kurang melatihkan keterampilan berpikir kreatif. Mengingat betapa pentingnya melatihkan keterampilan berpikir kreatif dalam proses pembelajaran, maka diperlukan suatu model pembelajaran. Salah satu alternatif model pembelajaran yang dipandang mampu melatihkan keterampilan berpikir kreatif yaitu model pembelajaran ICARE (Introduction, Connection, Application, Reflection, and Extension). Model pembelajaran ICARE ini pertama kali diperkenalkan pada tahun 1997 oleh Bob Hoffman dan Donn Ritchie di San Diego State University. United Stated Agency International Development (USAID) Indonesia melalui program Decentralized Basic Education (DBE) pada tahun 2006 mengenalkan dan menggunakan kerangka ICARE pada pelatihan guru dan peserta didik. Terdapat lima tahapan model pembelajaran ICARE yang disesuaikan dengan pembelajaran fisika, yaitu: tahap introduction, pada tahap ini peserta didik diberikan motivasi dan apersepsi untuk meningkatkan rasa ingin tahu melalui pertanyaan arahan yang berhubungan dengan konsep yang akan dipelajari, tahap connection guru menghubungkan pengetahuan yang sudah dimiliki peserta didik dengan apa yang akan dipelajari, sehingga dapat membangun pengetahuannya sendiri dan dapat menumbuhkan keterampilan berpikir kreatif, tahap application peserta didik diberikan kesempatan untuk menerapkan konsep dalam kegiatan eksperimen dan menyelesaikan permasalahan dalam konteks dunia nyata yang bersifat open ended untuk diselesaikan menggunakan konsep yang sudah mereka peroleh pada tahap sebelumnya, pada tahap reflection dan extention peserta didik diberi kesempatan untuk mengulang kembali secara singkat pembelajaran yang telah dilakukan untuk menambah wawasan, sehingga pengetahuan peserta didik menjadi lebih kuat dan bertahan lama (Hoffman \& Ritchie, 1998).

Berdasarkan pemaparan tersebut, tujuan dari penelitian ini untuk menguji mengenai efektivitas model pembelajaran ICARE dalam meningkatkan keterampilan berpikir kreatif peserta didik pada materi alat optic.

\section{METODE}

Penelitian ini menggunakan metode eksperimen semu (quasi experiment) dengan pretest posttest control group design (Creswell, 2010).

Tabel 1. Desain penelitian

\begin{tabular}{ccc}
\hline Pretest & Treatment & Posttest \\
\hline $\mathrm{O}_{1}$ & $\mathrm{X}$ & $\mathrm{O}_{1}$ \\
\hline
\end{tabular}

Keterangan:

$\mathrm{O}_{1} \quad$ : Pretest dan Posttest Keterampilan berpikir kreatif

X : Pembelajaran menggunakan model ICARE

Populasi pada penelitian ini adalah kelas XI IPA SMA berjumlah lima kelas. Pengambilan sampel dilakukan dengan metode simple random sampling yang mensyaratkan populasi homogen (Sugiyono, 2011). Populasi 
homogen berarti setiap kelas dalam populasi memiliki keadaan yang sama atau tidak ada bedanya antara satu kelas dengan kelas yang lain. Penentuan populasi homogen dengan menggunakan uji homogenitas dan uji normalitas. Instrumen yang digunakan berupa 12 butir soal uraian keterampilan bepikir kreatif yang mengandung pada enam aktivitas yaitu bertanya, menerka sebab-sebab suatu kejadian, menerka sebab akibat suatu kejadian, memperbaiki hasil keluaran, kegunaan suatu objek dan menuliskan hal lain dari suatu peristiwa. Soal yang dirancang sudah memenuhi kriteria validitas dan reliabilitasnya.

Uji homogenitas menggunakan Uji-F untuk mengetahui sampel penelitian dalam keadaan homogen. Uji normalitas dengan Uji Shapiro-Wilk untuk menunjukan data dalam keadaan terdistribusi normal. Teknik analisis data menggunakan statistic parametrik dengan mengasumsukan data terdistribusi normal dan homogen. Statistic parametrik menggunakan Paired T-test untuk mengetahui pengaruh dan uji N-Gain untuk mengetahui peningkatan kemampuan berpikir kreatif serta uji effect size untuk mengetahui besar efek dari model pembelajaran ICARE dalam meningkatkan keterampilan berpikir kreatif peserta didik pada materi alat optic.

\section{HASIL DAN PEMBAHASAN}

Berdasarkan data yang didapatkan, maka diperoleh hasil berupa uji normalitas, uji homogenitas, uji hipotesis, N-Gain dan uji Effect Size.

\section{Uji normalitas}

Uji normalitas skor pretest dan posttest dihitung dengan menggunakan uji Saphiro wilk.

Tabel 2. Hasil Uji Normalitas.

\begin{tabular}{lcc}
\hline \multirow{2}{*}{ Uji Norm } & \multicolumn{2}{c}{ Shapiro-wilk } \\
\cline { 2 - 3 } & Hasil Hitung & Hasil Tabel \\
\hline Pretest & 0,9809 & 0,916 \\
\hline Posttest & 0,9365 & 0,916 \\
\hline
\end{tabular}

Tabel 2. menunjukkan hasil uji normalitas yang dilakukan pada saat kemampuan awal (pretest) dan kemampuan akhir (Posttest) keterampilan berpikir kreatif, maka dapat disimpulkan berdasarkan kriteria bahwa hasil Lnitung $>$ Ltabel, maka sampel data berasal dari populasi yang berdistribusi secara normal.

\section{Uji Homogenitas}

Pengujian homogenitas dalam penelitian ini menggunakan uji F. Pengujian ini dilakukan untuk mengetahui data hasil pretest dan posttest berasal dari populasi yang memiliki variasi sama. Diperoleh hasil perhitungan varian data pretest 64,897 dan data posttest 166,520. Sehingga didapat $F_{\text {hitung }} 0,389$ dan nilai $F_{\text {tabel }}$ pada taraf signifikansi 0,05 sebesar 0,496 . Sehingga didapat hasil $F_{\text {hitung }}<F_{\text {tabel }}$ yang artinya bahwa data berasal dari sampel penelitian ysnghomogen.

\section{Uji Hipotesis}

Pengujian hipotesis dalam penelitian ini menggunakan Uji Paired T-Test, pengujian ini dilakukan untuk mengetahui hasil perbedaan yang diperoleh ketika diterapkan model pembelajaran ICARE dalam meningkatkan keterampilan berpikir kreatif. Penggunaan uji ini diterapkan berdasarkan syarat yang telah dipenuhi, antara lain sampel yang digunakan merupakan sampel dengan populasi terdistribusi secara normal. Untuk pengujian homogenitas tidak diperlukan dalam pengujian Paired T-Test, hal ini dikarenakan sampel yang diujikan berasal dari populasi yang sama dengan nilai varians yang saling berhubungan. Varians yang dimaksudkan dalam pengujian paired T-Test ini adalah nilai pretest dan posttest. Pengujian Paired T-Test dilakukan menggunakan Ms. Excel dengan taraf signifikansi 0,05. Hipotesis tersebut dirumuskan dalam bentuk hipotesis statistik sebagai berikut: $\mathrm{H}_{\mathrm{o}}: \mu_{1}=\mu_{2}$ : (Tidak terdapat perbedaan rata-rata skor sebelum dan sesudah diterapkan model pembelajaran ICARE)

$\mathrm{H}_{1}: \mu_{1} \neq \mu_{2}$ : (Terdapat perbedaan rata-rata skor sebelum dan sesudah diterapkan model pembelajaran ICARE).

Berdasarkan pehitungan didapatkan nilai thitung $>$ tabel yaitu $13,75>1,679$ dengan taraf signifikansi 0,05 , maka dapat disimpulkan bahwa Ho ditolak. Dengan demikian dapat disimpulkan terdapat perbedaan secara signifikan rata-rata hasil belajar peserta didik untuk Pretest dengan Posttest pada keterampilan berpikir kreatif. Sehingga adanya pengaruh model pembelajaran ICARE dalam meningkatkan keterampilan berpikir kreatif pada materi alat-alat optik.

\footnotetext{
Hasil N-Gain

Penelitian ini dilakukan pengujian pada tahap pretest dan posttest. Pengujian pretest dan posttest merupakan langkah awal untuk mengetahui seberapa besar keterampilan berpikir kreatif peserta didik dalam memahami suatu materi yang telah diberikan. Menentukan tingkat pemahaman materi secara keterampilan berpikir kreatif dapat diperoleh dengan menggunakan rata-rata skor $\mathrm{N}-$ Gain yang dinormalisasi $<\mathrm{g}>$ pada saat pretest dan posttest. Hasil penelitian diperoleh data tes awal (pretest) dan tes akhir (posttest) keterampilan berpikir kreatif. Tingkat peningkatan keterampilan berpikir kreatif dapat
} 
diterjemahkan dengan melihat kategori (Hake, 1998).

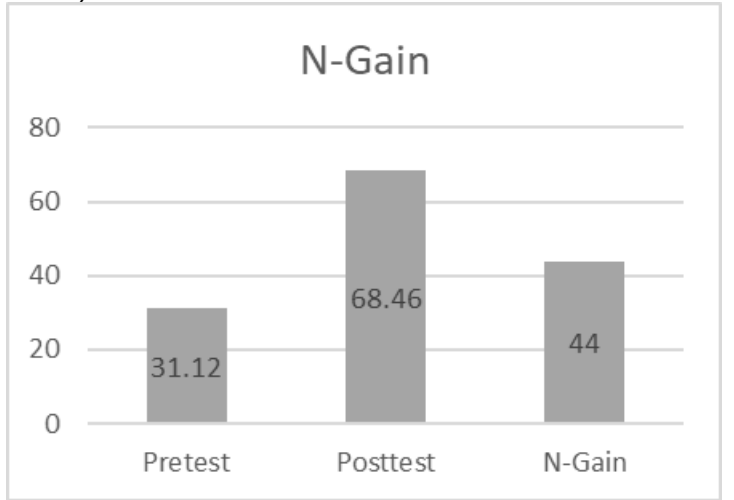

Gambar 1. Hasil N-Gain

Berdasarkan gambar 1, menunjukkan hasil rata-rata gain ternormalisasi untuk nilai pretest dan posttest pada keterampilan berpikir kreatif peserta didik pada materi alat-alat optik, setelah diimplementasikan model pembelajaran ICARE. Skor rata-rata nilai pretest peserta didik diperoleh sebesar 31,12 dan nilai posttest peserta didik setelah diterapkan pembelajaran ICARE mengalami peningkatan, dengan skor rata-rata 68,46. Pada N-gain keterampilan berpikir kreatif peserta didik skor rata-rata pretest dan rata-rata posttest diperoleh nilai sebesar 0,44, nilai $N$-gain ini termasuk dalam kategori sedang. Hal ini menunjukkan tentang keterampilan berpikir kreatif peserta didik termasuk dalam kategori sedang, setelah dilakukan penerapan model pembelajaran ICARE. Peningkatan pada kategori sedang ini memiliki banyak faktor yang mempengaruhinya diantaranya peserta didik yang belum terbiasa berada dalam kelas untuk melakukan pembelajaran, adaptasi dengan lingkungan cukup mempengaruhi, ditambah dengan tidak adanya infocus yang bisa digunakan sehingga menjadi kendala untuk proses pembelajaran, peserta didik terbiasa dengan menjawab dengan serempak, sehingga sangat sulit untuk melatihkan keterampilan komunikasi ilmiah tulisan. Seiring dengan berjalannya waktu, kebiasaan tersebut berangsur menjadi lebih baik, siswa berani mengungkapkan pendapatnya.

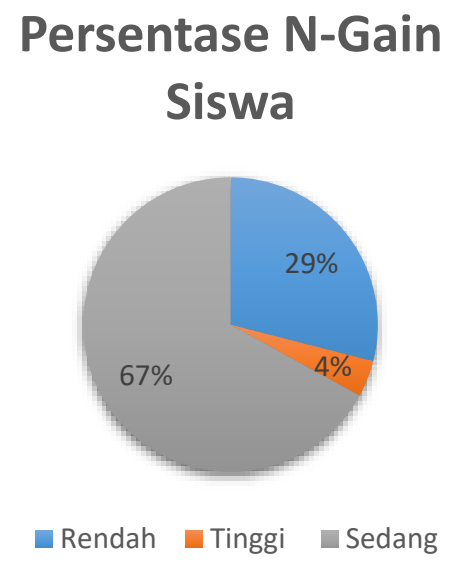

Gambar 2. Persentase N-Gain Peserta didik

Hasil persentase gain ternormalisasi peserta didik pada gambar 2 yang terdiri dari tiga kategori yang mana kategori rendah sebesar $29 \%$. Hal ini disebabkan karena saat proses pembelajaran yang dilakukan secara tatap muka, sebagian peserta didik kurang mampu untuk beradaptasi dengan lingkungan kelas, kurang menyimak informasi yang disampaikan sehingga sebagian peserta didik sering terlihat melamun. Pada kategori sedang mencapai $67 \%$, pencapaian ini disebabkan karena pada saat proses pembelajaran, kesempatan peserta didik untuk memberi pendapat serta menjawab pertanyaan tidak merata karena peserta didik terbiasa menjawab dengan serempak dan kurang berani untuk untuk tangan bertanya ataupun menjawab kemudian dari segi waktu yang yang tersedia sangat terbatas. Pencapain pada kategori tinggi mencapai $4 \%$, pencapain ini diperoleh karena pada saat proses pembelajaran sebagian siswa lebih aktif, selain itu selama proses pembelajaran siswa lebih berani mengungkapkan pendapatnya dan lebih aktif bertanya dalam kelas, saat posttest siswa mengupas lebih dalam permasalahan yang diberikan serta memberikan pendapat yang lebih ilmiah dan sesuai dengan permasalahan.

Terdapat beberapa aspek indikator dalam tes kemampuan berpikir kreatif yaitu fluency, flexibility, originality, elaboration. Tingkat peningkatan aspek tersebut dapat diterjemahkan dengan melihat kategori (Hake, 1998). 


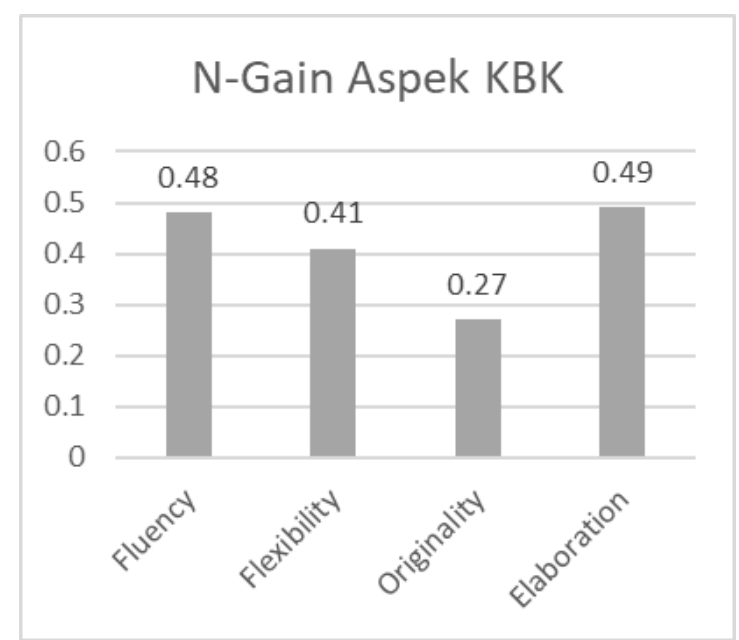

Gambar 3. N-Gain Aspek keterampilan berpikir kreatif

Berdasarkan gambar 3, pada aspek Fluency, Flexibility dan Elaboration berada dalam kategori sedang, sedangkan pada aspek Originality berada pada kategori rendah, dengan nilai $N$-Gain sebesar 0,27 . Hal ini menunjukkan tentang keterampilan berpikir kreatif peserta didik setelah dilakukan penerapan model pembelajaran ICARE.

\section{Uji Effect Size}

Berdasarkan hasil pengujian hipotesis menggunakan uji-t diperoleh perbedaan secara signifikan skor rata-rata pretest dan posttest pada keterampilan berpikir kreatif dengan menggunakan model pembelajaran ICARE. Oleh karena itu diperlukan perhitungan besar ukuran efeknya. Besarnya efek model pembelajaran ICARE dalam meningkatkan keterampilan berpikir kreatif dapat dilihat pada tabel 3.

\begin{tabular}{cccc}
\multicolumn{4}{c}{ Tabel 3. Hasil uji Effect Size } \\
\hline Rerata & Rerata & S $_{\text {gab }}$ & D $_{\text {cohen's }}$ \\
Pretest & Posttest & & \\
\hline 31,125 & 68,458 & 10,757 & 3,47 \\
\hline
\end{tabular}

Berdasarkan hasil perhitungan effect size, Efektivitas model pembelajaran ICARE Terhadap Keterampilan Berpikir Kreatif pada materi alat-alat optik terlihat dari hasil peningkatan $\mathrm{N}$-gain 0,44 yang masuk dalam kategori sedang, nilai pretest siswa mencapai 31,125 dan posttest 68,458. Dari hasil perhitungan didapat nilai Dcohen's sebesar 3,47 Sesuai dengan kriteria ukuran efek menurut Cohen, nilai $d$ termasuk pada kategori efek besar. Dapat dinyatakan bahwa tingkat efektivitas model pembelajaran ICARE dalam meningkatkan keterampilan berpikir kreatif, sangat tinggi atau sangat efektif. Hal ini dikarenakan pada setiap fase model pembelajaran ICARE pada materi alat-alat optic, dirancang untuk melatihkan keterampilan berpikir kreatif peserta didik.
Pada tahap introduction, melatih peserta didik untuk bertanya, menjawab pertanyaan ataupun mengungkapkan gagasannya, kemudian pada tahapan ini guru memberikan rangsangan agar peserta didik dapat melatih keterampilan berpikir kreatif melalui diskusi yang merujuk pada penggalian konsep awal. Pada tahap Connection terjadi tanya jawab antara guru dan peserta didik berdasarkan pengalaman atau pengetahuan yang sudah dimiliki peserta didik. Pada tahap ini juga guru menayangkan video pembelajaran terkait pembentukan bayangan untuk setiap alat optic yang dipelajari, dilanjutkan dengan kegiatan diskusi antar kelompok maupun dengan guru untuk menanamkan konsep alat optic. Pada tahap Application, peserta didik menerapkan konsep untuk menyelesaikan permasalahan sehari-hari dengan cara unik dan tidak biasa. Pada tahap reflection. peserta didik mengungkapkan apa yang telah dipelajari dan kesulitan yang dialami selama proses pembelajaran. Kemudian pada fase terakhir atau fase extention guru melakukan kegiatan penutup dan memberikan kesempatan kepada peserta didik untuk memperluas wawasannya terkait materi yang telah dipelajari.

\section{SIMPULAN DAN SARAN}

Model pembelajaran ICARE dalam meningkatkan keterampilan berpikir kreatif dengan nilai $\mathrm{N}$-Gain 0,44 yang artinya terdapat peningkatan yang berada pada kategori sedang, serta didapatkan nilai effect size sebesar 3,47 yang termasuk kedalam kategori efek besar. Hasil penelitian ini dapat disimpulkan bahwa dengan menggunakan model pembelajaran ICARE efektif dalam meningkatkan keterampilan berpikir kreatif.

Untuk peneliti, kedepannya akan meningkatkan kembali keterampilan berpikir kreatif khususnya pada aspek Originality.

\section{UCAPAN TERIMAKASIH}

Terimakasih kepada Dr.Ridwan Effendi dan Dr.Parsaoran Siahaan yang sudah memberikan masukan serta bimbingannya sehingga dapat terselesaikannya artikel ini.

\section{DAFTAR RUJUKAN}

Alzoubi, A. M., Al Qudah, M. F., Albursan, I. S., Bakhiet, S. F., \& Abduljabbar, A. S. (2016). The Effect of Creative Thinking Education in Enhancing Creative SelfEfficacy and Cognitive Motivation. Journal of Educational and Developmental $\begin{array}{lll}\text { Psychology, } & 6(1), & 117 .\end{array}$ https://doi.org/10.5539/jedp.v6n1p117

Arifin, Z. (2017). Mengembangkan Instrumen Pengukur Critical Thinking Skills Siswa 
pada Pembelajaran Matematika Abad 21.

Jurnal THEOREMS (The Original Research of Mathematics), 1(2), 92-100. http://jurnal.unma.ac.id/index.php/th/articl e/view/383/362

Binkeley Erstad, O., Herman, J., Raizen, S., Ripley, M. \& Rumble, M., M. (2010). Defining 21st century skills. Draft paper. Assessment \& Teaching of 21st century skills. Definiting Inclode for Future, 02(January), 50.

Creswell, J. . (2010). Research Design: Pendekatan kualitatif, kuantitatif dan mixed. PT. Pustaka Pelajar.

Hake, R. R. (1998). Interactive-engagement versus traditional methods: A sixthousand-student survey of mechanics test data for introductory physics courses. American Journal of Physics, 66(1), 6474. https://doi.org/10.1119/1.18809

Hoffman, B., \& Ritchie, D. (1998). Teaching and Learning Online: Tools, Templates, and Training. Society for Information Technology \& Teacher Education International Conference, 119-123. https://files.eric.ed.gov/fulltext/ED421092. pdf

Kivunja, C. (2015). Exploring the Pedagogical Meaning and Implications of the 4Cs "Super Skills" for the 21\&lt;sup\&gt;st\&lt;/sup\&gt; Century through Bruner's 5E Lenses of Knowledge Construction to Improve Pedagogies of the New Learning Paradigm. Creative Education, 06(02), 224-239. https://doi.org/10.4236/ce.2015.62021

Sugiyono. (2011). Metode Penelitian Kuantitatif, Kualitatif, dan R\&D. CV. Alfa Beta.

Torrance, E. P. (1990). The Torrance Tests of Creative Thinking Norms-Technical Manual Figural (Streamlined) Forms A \& B. Bensenville, IL: Scholastic Testing Service, Inc.

Trilling, B., \& Fadel, C. (2009). Bernie Trilling, Charles Fadel-21st Century Skills_ Learning for Life in Our Times -JosseyBass (2009). Journal of Sustainable Development Education and Research, 2(1), 243.

Wibowo, F. C., \& Suhandi, A. (2013). Penerapan model science creative learning (SCL) fisika berbasis proyek untuk meningkatkan hasil belajar kognitif dan keterampilan berpikir kreatif. Jurnal Pendidikan IPA Indonesia, 2(1), 67-75. https://doi.org/10.15294/jpii.v2i1.2512 